\section{THU0034 HIGHER IL-10 CONCENTRATIONS IN THE SYNOVIAL FLUID FROM RA PATIENTS WHEN COMPARED WITH SPONDYLOARTHROPATHY-DERIVED FLUIDS}

B Moeller, U Kessler, N Kukoc-Zivojnov, J Kaltwasser. Centre for Rheumatic Diseases, University Hospital, Frankfurt, Germany

\subsection{6/annrheumdis-2001.831}

Background Several investigations of synovial fluid (SF) and membrane derived $\mathrm{T}$ cells show a predominant $\mathrm{Th} 1$ response with high IFN-gamma production from rheumatoid arthritis (RA), and a predominant Th2 response with high IL-4 and IL-10 production in T cells from spondyloarthropathy (SpA) joints.

Objectives To investigate the concentrations of IFN-gamma, TNF-alpha, IL-4, IL-10, the Th1 propagating cytokines IL-12 and IL-18, and the monokine IL-1 in sera and synovial fluids from RA and SpA patients.

Methods Patients were selected according to the ACR classification criteria for RA ( $n=13)$, and the ESSG classification criteria for $\mathrm{SpA}(\mathrm{n}=14)$. Cytokine concentrations were measured using commercial ELISA kits. Results are expressed as mean \pm standard deviation, significance was calculated using the Mann-Whitney U-test for untailed groups. Sera from 8 healthy donors served as controls.

Results IFN-gamma concentrations were significantly lower (4,3 $\pm 2,6 \mathrm{pg} / \mathrm{ml})$, but IL-18 (78,8 $\pm 29,3 \mathrm{pg} / \mathrm{ml})$, TNF-alpha $(105,4$ $\pm 40,9 \mathrm{pg} / \mathrm{ml})$, and IL-10 $(100,1 \pm 69,7 \mathrm{pg} / \mathrm{ml})$ concentrations were significantly higher in RA than in SpA-SF (IFN-gamma $12,9 \pm 10,4 \mathrm{pg} / \mathrm{ml}, \mathrm{p}=0,009$, IL-18 55,1 $\pm 44,1 \mathrm{pg} / \mathrm{ml}, \mathrm{p}=$ 0,038, TNF-alpha 74,1 $\pm 85,0 \mathrm{pg} / \mathrm{ml}, \mathrm{p}=0,044$, IL-10 14,1 \pm $19,9, \mathrm{p}<0,0001)$. IL-4 and IL-12 concentrations were rather low in RA- and SpA-SF. Serum concentrations of all investigated cytokines in RA and SpA differed - if at all -only marginally from the situation in healthy donors.

Conclusion Synovial fluid concentrations of the Th1 and Th2 cytokines in RA and SpA do not generally reflect the state of Th1/Th2 balance at the single cell level. There is strong evidence for substantially higher amounts of IL-10 in RA than SpA synovium, reflecting strong antiiflammatory processes are present in RA synovium. The observed Th1/Th2 balances in both investigated diseases are not explained by the corresponding IL-12 and IL-18 SF concentrations.

\section{THU0035 CYTOKINE PRODUCTION BY CD3 ${ }^{+}$T CELL IN SYNOVIAL FLUID FROM PATIENTS AFFECTED BY PSORIATIC ARTHRITIS AND RHEUMATOID ARTHRITIS}

${ }^{1} \mathrm{~L}$ Riente, ${ }^{2} \mathrm{~F}$ Pratesi, ${ }^{1} \mathrm{~S}$ Frigelli, ${ }^{1} \mathrm{~A}$ Delle Sedie, ${ }^{2} \mathrm{M}$ Scavuzzo, ${ }^{2} \mathrm{D}$ Chimenti, ${ }^{2} \mathrm{P}$ Migliorini. ${ }^{1}$ Medicina Interna, UO Reumatologia; ${ }^{2}$ Medicina Interna, UO Immunologia, Università Di Pisa, Pisa, Italy

\subsection{6/annrheumdis-2001.832}

Background Psoriatic arthritis (PsA) is an inflammatory arthropathy associated with psoriasis, characterised by synovitis which often leeds to destruction of cartilage and bone.

The mechanism of joint damage is unclear, but it's likely that cytokines play critical roles. In PsA cytokines have been previously measured by enzyme-linked immunoassays; however, these molecules are not very stable in inflammatory fluids and are detectable only when produced in large amount.

Objectives The aim of our study was to analyse the cytokines production in synovial fluids of patients affected by psoriatic arthritis.
Methods We analysed cytokines production ex vivo by single cell analysis in flow cytometry in synovial fluids of 9 patients affected by PsA. As control group we used synovial fluids from 8 patients affected by Rheumatoid Arthritis (RA). Synovial fluid leukocytes isolated on Ficoll gradients were stimulated with phorbol-myristate-acetate and ionomycin, treated with brefeldin, permeabilized and stained with anti-CD3, anti-IL4 and antiIFNg.

Results In 9 patients affected by PsA, IFNg-producing cells were the vast majority $(43 \%, 46 \%, 75 \%, 55 \%, 51 \%, 42 \%, 38 \%$, $32 \%, 20 \%$ of $\mathrm{CD}^{+}$cells). A similar predominance was observed in 8 patients with rheumatoid arthritis $(64 \%, 36 \%, 35 \%, 75 \%$, 38\%, 29\%, 46\%, 26\%).

Conclusion IFNg is the typical cytokine produced by TH1 T cells, thus the results of our study suggest that TH1 T cell selectively home to synovial tissue in PsA, as already shown in RA.

A better understanding of cytokine production in psoriatic arthritis synovium in a larger number of patients may help to clarify the pathogenesis of the disease and lead to the development of more specific and effective therapeutic agents.

\section{REFERENCE}

1 Nuti S, Rosa D, Valiante NM, Saletti G, Caratozzolo M, Dellabona P, Barnaba V, Abrignani $S$. Dynamics of intra-hepatic lymphocytes in chronic hepatitis $C$ : enrichment for Va24+ Tcells and rapid elimination of effector cells by apoptosis. Eur $J$ Immunol. 1998;28:3448-56

\section{THU0036 THE EFFECT OF INFLIXIMAB ON PLASMA LIPOPROTEINS}

MM Spak, EC Cauza, KC Cauza, UH Hanusch-Enserer, AD Dunky, KK Kostner. Department of Rheumatology/Medicine 5, Wilhelminenspital, Vienna, Austria

\subsection{6/annrheumdis-2001.833}

Background We investigated the effect of Infliximab, a mousehuman chimaeric monoclonal antibody that binds and inhibits the activity of TNF a, on Lipid Metabolism in patients with Rheumatoid arthritis (RA) and Psoriatic arthritis (Psa).

\section{Objectives}

Methods Fifteen persons hospitalised in our division of rheumatology were studied. Over a period of eight months 5 male and 10 female patients with a mean age of 56,7 years (age range: 30-81) were included in this study. The subjects included 7 patients with rheumatoid arthritis (RA) according to the ARA criteria (12) and 8 patients with Psoriatic arthritis (PsA). Eight patients had been treated with methotrexat (MTX), 4 with other DMARDs than MTX, 2 patients only received NSAIDs and 5 corticosteroids. Treatment resistant patients with active disease (fulfilling inclusions criteria) received infusions of $3 \mathrm{mg} / \mathrm{kg}$ infliximab (at week 0, 2, 614,22 and 30). Two of the patients received $4 \mathrm{mg} / \mathrm{kg}$ infliximab after 14 weeks. Lipoprotein (a), Cholesterol, triglycerides, LDL-cholesterol and HDL-cholesterol were measured by commercially available kits from Boehringer Mannheim (Mannheim, Germany).

Results Infliximab was well tolerated; no toxic effects were observed, no major abnormalities in hematologic findings were noted during or after the study. There was no significant difference either in total cholesterol before and after treatment (209 \pm 25 vs. $25 \pm 36 \mathrm{mg} / \mathrm{dl})$ or in LDL-cholesterol $(1311 \pm 24$ vs. $1188 \pm 4 \mathrm{mg} / \mathrm{dl}$ ). Lp (a) levels also did not show a change during treatment (median: 1,1 vs. $1,4 \mathrm{mg} / \mathrm{dl}$ ). However there was a significant rise in triglyceride (TG) levels during treatment with Remicade $(1122 \pm 48$ vs. $1333 \pm 5 \mathrm{mg} / \mathrm{dl}, \mathrm{p}<0.01)$. HDL levels on the other hand were significantly lowered (566 \pm 12 vs. 